Provided for non-commercial research and education use. Not for reproduction, distribution or commercial use.



This article appeared in a journal published by Elsevier. The attached copy is furnished to the author for internal non-commercial research and education use, including for instruction at the authors institution and sharing with colleagues.

Other uses, including reproduction and distribution, or selling or licensing copies, or posting to personal, institutional or third party websites are prohibited.

In most cases authors are permitted to post their version of the article (e.g. in Word or Tex form) to their personal website or institutional repository. Authors requiring further information regarding Elsevier's archiving and manuscript policies are encouraged to visit:

http://www.elsevier.com/copyright 


\title{
Benzene dispersion and natural attenuation in an alluvial aquifer with strong interactions with surface water
}

\author{
Jordi Batlle-Aguilar $^{\mathrm{a}, 1}$, Serge Brouyère ${ }^{\mathrm{a}, *}$, Alain Dassargues ${ }^{\mathrm{a}}$, Barbara Morasch ${ }^{\mathrm{b}, 2}$, Daniel Hunkeler ${ }^{\mathrm{b}}$, \\ Patrick Höhener ${ }^{b, 3}$, Ludo Diels ${ }^{c}$, Karolien Vanbroekhoven ${ }^{c}$, Piet Seuntjens ${ }^{c}$, Henri Halen ${ }^{\mathrm{d}}$ \\ ${ }^{a}$ Department ArGEnCo, Hydrogeology Unit and Aquapôle, University of Liège, Building B52/3, B-4000 Sart Tilman, Belgium \\ ${ }^{\mathrm{b}}$ Centre for Hydrogeology, University of Neuchâtel, Rue Emile-Argand 11, CH-2009 Neuchâtel, Switzerland \\ ${ }^{\mathrm{c}}$ Flemish Institute for Technological Research, VITO, Boeretang 200, B-2400 Mol, Belgium \\ d Société Publique d'Aide à la Qualité de l'Environnement, SPAQuE, Boulevard d'Avroy 38/6, B-4000 Liège, Belgium
}

\section{A R T I C L E I N F O}

\section{Keywords:}

Groundwater

Brownfield

Benzene

Stable isotope fractionation

Natural attenuation

Groundwater-surface water interaction

\begin{abstract}
S U M M A R Y
Field and laboratory investigations have been conducted at a former coke plant, in order to assess pollutant attenuation in a contaminated alluvial aquifer, discharging to an adjacent river. Various organic (BTEX, PAHs, mineral oils) and inorganic (As, Zn, Cd) compounds were found in the aquifer in concentrations exceeding regulatory values. Due to redox conditions of the aquifer, heavy metals were almost immobile, thus not posing a major risk of dispersion off-site the brownfield. Field and laboratory investigations demonstrated that benzene, among organic pollutants, presented the major worry for off-site dispersion, mainly due to its mobility and high concentration, i.e. up to $750 \mathrm{mg} \mathrm{L}^{-1}$ in the source zone. However, benzene could never be detected near the river which is about $160 \mathrm{~m}$ downgradient the main source. Redox conditions together with benzene concentrations determined in the aquifer have suggested that degradation mainly occurred within $100 \mathrm{~m}$ distance from the contaminant source under anoxic conditions, and most probably with sulphate as main oxidant. A numerical groundwater flow and transport model, calibrated under transient conditions, was used to simulate benzene attenuation in the alluvial aquifer towards the Meuse River. The mean benzene degradation rate used in the model was quantified in situ along the groundwater flow path using compound-specific carbon isotope analysis (CSIA). The results of the solute transport simulations confirmed that benzene concentrations decreased almost five orders of magnitude $70 \mathrm{~m}$ downgradient the source. Simulated concentrations have been found to be below the detection limit in the zone adjacent to the river and consistent with the absence of benzene in downgradient piezometers located close to the river reported in groundwater sampling campaigns. In a transient model scenario including groundwater-surface water dynamics, benzene concentrations were observed to be inversely correlated to the river water levels, leading to the hypothesis that benzene dispersion is mainly controlled by natural attenuation.
\end{abstract}

(C) 2009 Elsevier B.V. All rights reserved.

\section{Introduction}

Sites of former industrial activities are often located near navigable rivers to facilitate the transport operations of industrial raw materials. This has resulted nowadays in the existence of numer-

\footnotetext{
* Corresponding author. Tel.: +32 436623 77; fax: +32 43669520.

E-mail address: serge.brouyere@ulg.ac.be (S. Brouyère).

1 Present address: Ecological Engineering Laboratory, Institute des Sciences et Technologies de l'Environnement, École Polytechnique Fédérale de Lausanne, Station 2, Building GR, CH-1015, Lausanne, Switzerland.

2 Present address: Environmental Chemistry Laboratory, Institute des Sciences et Technologies de l'Environnement, École Polytechnique Fédérale de Lausanne, Station 2, Building CM, CH-1015 Lausanne, Switzerland.

${ }^{3}$ Present address: Equipe Chimie de l'Environnement Continental, UMR 6264, Laboratoire Chimie Provence, Université de Provence-CNRS, 3 Place Victor Hugo, Case 29, F-13331 Marseille Cedex 3, France.
}

ous contaminated sites located in clusters close to rivers, in relatively urbanised areas. These sites often pose a major risk of dispersion in the environment and the exposure of human beings and ecosystems to contaminants, mainly by possible migration to surface water through groundwater discharge. This is particularly critical because of the possible cumulative effect of the different active pollution sources when several contaminated sites are located within the same water system(s). These sites, most of which could be defined as brownfield, are typically polluted by aromatic hydrocarbons such as benzene, toluene, ethylbenzene, xylene (BTEX), polycyclic aromatic hydrocarbons (PAHs) and heavy metals such as $\mathrm{Zn}$, As or $\mathrm{Cd}$, which belong to the major contaminants in groundwater (Lovley, 2000; Khan et al., 2005; Lee et al., 2006; Fischer et al., 2007). These compounds are of a particular environmental concern, since they represent a significant health risk because of their high recalcitrance and toxicity; several of these are 
even known as human carcinogens (Burland and Edwards, 1999; Fischer et al., 2007). The concept of "natural attenuation" covers all physical, chemical and biological processes that help to reduce the mass of dissolved contaminants in a groundwater plume, such as dispersion, sorption, volatilisation, biological and chemical degradations (Wiedemeier et al., 1999).

Risks associated with dispersion of contaminants are intimately related to two main factors: the occurrence of water transfers between the various components of the soil-groundwater-surface water compartments as well as the mobility and persistence of identified contaminants through such compartments. At a single contaminated site scale, the first step is to characterise and quantify, as accurately as possible, water and contaminant fluxes.

Important insights have been gained in the study of biogeochemical and physical processes affecting the mobility and attenuation of contaminants in aquifers. Little attention, however, has been paid to the fate of contaminants and processes affecting the spatial distribution before they reach the river-aquifer interface of a polluted site with strong groundwater-surface water interactions. The determining factors for future evolution of these contaminants must still be defined. For example and at the aquifer level, heterogeneity is rarely addressed in studies on groundwater-surface water interactions and pollutant discharge (Wroblicky et al., 1998; Conant et al., 2004; Fleckenstein et al., 2006). Kao and Wang (2000) observed in a sandy-silty-loamy aquifer not subject to river interactions, an important drop in BTEX concentration $100 \mathrm{~m}$ downstream of the source area, which was related to iron and nitrate reduction; Lee et al. (2001) observed that hydrostratigraphy, seasonal recharge and biodegradation were the most important factors controlling the distribution of hydrocarbon contaminants within a sandy aquifer; and Fritz and Arntzen (2007) demonstrated a relation between hydraulic gradient changes due to river fluctuations and uranium fluxes discharging to the river.

This study focuses on the characterisation and quantification of water and contaminant fluxes in the groundwater-surface water system corresponding to the alluvial aquifer of the Meuse River, located in the brownfield of a former coke and gas factory in the Liège area, in Belgium. At first, a brief description of the study site as well as the investigations performed to assess groundwater hydrodynamic and hydrodispersive properties and groundwatersurface water interactions are presented. In a second step, we present the hydrogeochemical conditions together with the organic and inorganic pollutants fate in groundwater, which are analysed to identify which contaminants are of stronger concern with respect to off-site dispersion risks. Afterwards, a numerical groundwater flow and contaminant transport is presented, which is used to evaluate different scenarios of benzene dispersion in groundwater. Finally, results are discussed including all information gathered by means of laboratory, field studies and modelling approaches. Our objectives are reached by combining laboratory and field investigations as well as advanced numerical modelling of groundwater flow and contaminant transport in the alluvial aquifer.

\section{General description of the study site}

The study site is a brownfield of $400 \mathrm{~m}$ length and $250 \mathrm{~m}$ width, corresponding to the location of a former coke and gas factory. It is located at $25 \mathrm{~m}$ distance to the North bank of the Meuse River (Fig. 1), upstream the city of Liège (Belgium), in an industrial environment where urban cores developed during the last century. The facility was active from 1922 until 1984 when it was dismantled and abandoned.
The top-bottom geology of the site consists of $4 \mathrm{~m}$ backfill deposits, $2 \mathrm{~m}$ silt-sand-clay deposits and approximately $8 \mathrm{~m}$ alluvial gravels (mean thickness) deposited over a carboniferous shale bedrock, which is the impervious lower boundary for the alluvial aquifer. The main aquifer is located in the alluvial gravels, with a groundwater table fluctuating around $7 \mathrm{~m}$ typical mean depth. The topography is very flat with a general groundwater flow direction towards the Meuse River direction, with a low hydraulic gradient of $0.3 \%$ (Batlle-Aguilar and Brouyère, 2005, 2006).

In order to allow navigation and to prevent flooding of the alluvial plain, the river water level is controlled by dams (located $1.5 \mathrm{~km}$ upstream and $14 \mathrm{~km}$ downstream the brownfield, respectively), that keep the river water level at a $59.4 \mathrm{~m}$ a.s.l. (above sea level) baseline in that section of the river corresponding to the brownfield. River water levels fluctuate continuously with amplitudes varying from a few centimeters under its baseline and up to $2 \mathrm{~m}$ locally during winter-spring seasons.

Past characterisation campaigns evidenced important soil and groundwater contamination by organic compounds, mainly BTEX, PAHs and also by heavy metals. Benzene concentrations in groundwater were reported to be up to $750 \mathrm{mg} \mathrm{L}^{-1}$ in the source zone at the monitoring campaign in 2005 and up to $18 \mathrm{mg} \mathrm{L}^{-1}$ in 2006 . Toluene and xylene were found at 77 and $15 \mathrm{mg} \mathrm{L}^{-1}$ ( 3 and $0.6 \mathrm{mg} \mathrm{L}^{-1}$ in 2006), respectively (SPAQUE, Sociétée Publique d'Aide à la Qualité de l'Environnement, internal report). Polycyclic aromatic hydrocarbons, like naphthalene, acenaphthene and fluoranthene, were present in the groundwater, at concentrations up to $3 \mathrm{mg} \mathrm{L}^{-1}$ (25 $\mathrm{mg} \mathrm{L}^{-1}$ in 2006). Heavy metals were also found in groundwater at maximum concentrations of $5 \mu \mathrm{g} \mathrm{L}^{-1}$ for $\mathrm{Cd}, 10 \mu \mathrm{g} \mathrm{L} \mathrm{L}^{-1}$ for As and $\mathrm{Pb}$, and $200 \mu \mathrm{g} \mathrm{L}^{-1}$ for $\mathrm{Zn}$. In the source area, groundwater was anoxic with negative Eh values down to $-300 \mathrm{mV}$ and nitrate was found to be near-total depletion (ranging from 0 to $3 \mathrm{mg} \mathrm{L}^{-1}$ ). Background nitrate concentrations of $190 \mathrm{mg} \mathrm{L}^{-1}$, outside of the brownfield, were recorded upgradient. Downstream, towards the Meuse River, Eh values of $+100 \mathrm{mV}$ were observed and nitrate concentrations up to $15 \mathrm{mg} \mathrm{L}^{-1}$ were reported. Sulphate, that is also a by-product of coke manufacturing, was heterogeneously distributed over the totality of the aquifer, with concentrations typically ranging from 500 to $2100 \mathrm{mg} \mathrm{L}^{-1}$. It is worth noting that all piezometers and monitoring wells were single screened, thus providing depth-integrated measurements.

\section{Characterisation of groundwater flow and transport conditions in the alluvial aquifer interacting with the river}

To improve the current knowledge on the hydrodynamic and hydrodispersive properties of the alluvial aquifer and the possible interactions with the Meuse River, groundwater level fluctuations were monitored and, pumping tests and tracer experiments were performed (Batlle-Aguilar and Brouyère, 2005, 2006).

Monitoring and analysis of interactions between rainfall, groundwater and surface water

Groundwater level fluctuations were monitored hourly using pressiometric-temperature LevelTroll ${ }^{\circledR}$ probes (time resolution: $1 \mathrm{~h}$ ). Two of these probes were placed in observation wells located along an orthogonal section near and far from the river (wells U5 and U3) on an almost permanent basis over a 2 year period. Two more pressiometric probes were used by pairs in observation wells (near and far from the river) for shorter periods of time (1 month). Altogether, 16 observation wells were distributed all over the field and monitored during 2 years (Fig. 1). During that same period, the Meuse surface water level, temperature and discharge were continuously monitored at a hydroelectric plant located on the 




Fig. 1. Location of the studied brownfield. The main pollutant source is indicated with a dark ellipse, and the 16 wells monitored with pressiometric probes TrollLevel ${ }^{\circledR}$ are shown. Symbols of these wells agree to corresponding field works performed. Piezometric lines correspond to the monthly groundwater head survey in June 2005.

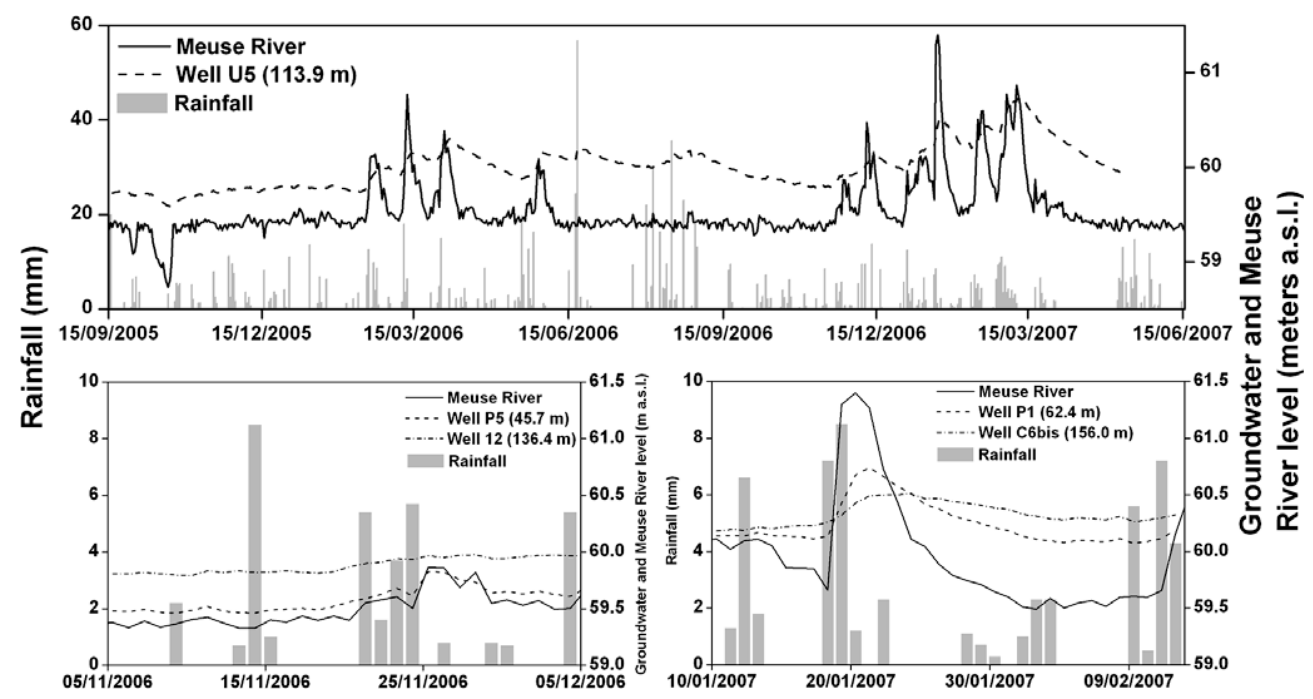

Fig. 2. Surface water level fluctuations of the Meuse River and groundwater heads at selected wells for different periods. Rainfall recorded $1.5 \mathrm{~km}$ upstream of the site is also depicted. Distance of the wells to the aquifer-river interface is indicated in brackets.

opposite river bank, in front of the brownfield. Daily rainfall data were available for the Ivoz-Ramet dam, located $1.5 \mathrm{~km}$ upstream the brownfield site.
Monitored groundwater heads, river levels and rainfall data (Fig. 2) were analysed for time cross-correlations using the BRGM TEMPO $^{\circledR}$ software (Pinault, 2001) with hourly data, except for 
precipitation. For the latter, only daily data was available. Crosscorrelation coefficients between river water levels and groundwater levels ranged from 0.8 to 0.98 for wells located close to the river. As expected, the correlation decreases as the distance to the river increases, while the time lag response increases. This can be conceptualised in the form of a wave propagation into the aquifer, which amplitude is progressively attenuated and the time lag is increased (Sophocleous, 1991; Jha et al., 2004; Ha et al., 2007). The same cross-correlation analyses showed that rainfall plays a secondary role in groundwater level fluctuations, with maximum cross-correlation coefficients of 0.3. Details on these correlation analyses can be found in Batlle-Aguilar (2008).

\section{Hydrodynamic and hydrodispersive properties of the alluvial aquifer}

Six pumping tests and five slug tests were performed in selected wells of the site (results not shown). Estimated saturated hydraulic conductivity $(K s)$ values resulting from both, pumping and slug tests, range from $1 \times 10^{-5}$ to $1 \times 10^{-3} \mathrm{~m} \mathrm{~s}^{-1}$. These values are lower than expected for an alluvial aquifer and their spatial variability reveals the heterogeneity of the alluvial deposits.

Radially convergent tracer experiments were performed in order to assess the hydrodispersive properties (mostly the effective porosity $-\theta_{m}$ and the longitudinal dispersivity $-\alpha_{L}$ ), and to identify possible retardation, such as dual-porosity effects related to smallscale heterogeneities of the alluvial deposits that can be assimilated to immobile water (Herr et al., 1989; Li et al., 1994; Brouyère, 2001). Within the context of alluvial deposits, mobile water corresponds to that in the effective porosity, while immobile water (or less mobile) rather corresponds to water located in less pervious zones, mostly clay and silty sand with low saturated hydraulic conductivity than that of the gravels. Groundwater was pumped in well P5 until steady state radially convergent flow conditions were achieved. The tracers used for this experiment (eosin yellowish, uranin, naphtionate, sulforhodamine B, iodide and lithium) were instantaneously injected in well U15 (Fig. 1). The resulting breakthrough curves differed strongly from each other, mainly because of two factors: (1) the specific physico-chemical properties of each tracer and (2) changes of pumping rate at the recovery well to avoid dewatering the pumping well during lowering of groundwater levels. Measured breakthrough curves served subsequently to calibrate the groundwater transport model.

\section{Redox conditions and contaminant distribution}

From 1992, five groundwater monitoring campaigns have been performed by SPAQuE at the studied brownfield. Concentrations of various redox sensitive species in groundwater were determined in 2006 during a sampling campaign devoted to measurements of benzene concentrations and isotopic ratios (see "Assessment of benzene biodegradation using stable carbon isotope analysis" and "Natural attenuation of benzene" sections). Dissolved oxygen concentrations, temperature, electrical conductivity, and $\mathrm{pH}$ were recorded directly in the field, using specific field probes (WTW, Weilheim, Germany). Samples for the analysis of $\mathrm{Fe}^{2+}$ and $\mathrm{Mn}^{2+}$ were filtered $(0.45 \mu \mathrm{m})$ and acidified with concentrated $\mathrm{HNO}_{3}^{-}$directly in the field to prevent their oxidation. For colorimetric analysis, phenanthroline and 1-(2-pyridylazo)-2-naphthol were used (Goto et al., 1977; Stucki and Anderson, 1981). Samples for $\mathrm{HS}^{-}$ quantification were preserved in a Zn-acetate solution (2\%) directly in the field and analysed by colorimetry following the procedure of Cline (1969). For $\mathrm{CH}_{4}$ analyses, $40 \mathrm{~mL}$ VOC vials with Teflon-rubber septa were filled with $39 \mathrm{~mL}$ of a water sample and tightly sealed in the field. Back to the laboratory, head space samples were taken using a syringe through the septum and then analysed for $\mathrm{CH}_{4}$ using a gas chromatograph equipped with flame ionisation detection (Platen and Schink, 1987).

Redox conditions in the aquifer were determined on the analyses of $\mathrm{O}_{2}, \mathrm{NO}_{3}^{-}, \mathrm{Fe}^{2+}, \mathrm{Mn}^{2+}, \mathrm{SO}_{4}^{2-}, \mathrm{HS}^{-}$, and $\mathrm{CH}_{4}$ in groundwater sampled from 25 piezometers (Table 1 ). The results presented here focus on the most recent data from the campaign performed in 2006 (whenever helpful or complementary, data from 2005 campaign were used). The sampling points were located in the zone of major contamination with organic compounds and downgradient from this zone. Two reference wells (E6p and F4) were also sampled; these were located 92 and $74 \mathrm{~m}$ upgradient the major

Table 1

Benzene concentrations and corresponding stable isotope signatures in groundwater sampled from 25 different piezometers in 2006 . Electron acceptors and products related to the degradation of organic compounds are also presented. Piezometer D2bis, located in the main source zone, was defined as contaminant source. E6p and F4 are reference wells upgradient from this contamination (n.a.: not analysed).

\begin{tabular}{|c|c|c|c|c|c|c|c|c|c|}
\hline Well & Distance from source $(\mathrm{m})$ & $\delta^{13} \mathrm{C}$ & Benzene $\left(\mu \mathrm{g} \mathrm{L}^{-1}\right)$ & $\mathrm{CH}_{4}\left(\mu \mathrm{g} \mathrm{L}^{-1}\right)$ & $\mathrm{SO}_{4}^{2-}\left(\mathrm{mg} \mathrm{L}^{-1}\right)$ & $\mathrm{HS}^{-}\left(\mathrm{mg} \mathrm{L}^{-1}\right)$ & $\mathrm{NO}_{3}^{-}\left(\mathrm{mg} \mathrm{L}^{-1}\right)$ & $\mathrm{Fe}^{2+}\left(\mathrm{mg} \mathrm{L}^{-1}\right)$ & $\mathrm{Mn}^{2+}\left(\mathrm{mg} \mathrm{L}^{-1}\right)$ \\
\hline E6p & -92 & n.a. & $<0.02$ & n.a. & 737 & 0.1 & 16.3 & $<0.1$ & n.a. \\
\hline $\mathrm{F} 4$ & -74 & -24.0 & 0.09 & 1.3 & 925 & 1.2 & 66 & 12.3 & 3.4 \\
\hline D2bis & 0 & -24.8 & 206 & 267.7 & 311 & 18.1 & $<0.1$ & 0.3 & 1.4 \\
\hline C3bis & 11 & -21 & 20 & 0.6 & 863 & 0.4 & 0.3 & 11 & 6.8 \\
\hline D1p & 22 & -23.5 & 17,546 & 313 & 1112 & 2.9 & $<0.1$ & 23.3 & 5 \\
\hline D3p & 22 & -24.5 & 4949 & 68 & 1329 & 1.9 & 0.4 & 2 & 0.7 \\
\hline U9 & 25 & -21.8 & 0.47 & 8.1 & 1147 & 0.2 & 0.4 & 1.7 & 8 \\
\hline A3 & 26 & n.a. & $<0.02$ & 0.9 & 930 & $<0.1$ & 0.2 & 0.1 & 1.2 \\
\hline U5 & 34 & n.a. & $<0.02$ & 12.1 & 1127 & 0.1 & 1.8 & 10.2 & 6.7 \\
\hline U4 & 39 & -23.9 & 9763 & 156.2 & 21 & 13.9 & $<0.1$ & 1.6 & 2.4 \\
\hline 11 & 51 & -20.9 & 1.2 & 22.2 & 570 & 0.8 & $<0.1$ & 6.4 & 7.1 \\
\hline U6 & 54 & -23.0 & 1319 & 0.9 & 1352 & 7.7 & 0.2 & 0.1 & 2.4 \\
\hline U10 & 68 & -22.2 & 0.39 & 3.9 & 971 & 0.1 & 7.3 & 0.2 & 5 \\
\hline 14 & 79 & n.a. & 29 & 31.6 & 540 & 1.1 & 0.3 & 0.2 & 1.4 \\
\hline U13 & 88 & -21.0 & 0.38 & 1.1 & 728 & 0.2 & 19.7 & 0.1 & 3.8 \\
\hline 12 & 89 & -20.9 & 1 & 93.7 & 1103 & 0.2 & $<0.1$ & 7.4 & 7.4 \\
\hline 1 & 94 & n.a. & $<0.02$ & 4.5 & 614 & 0.3 & 1.5 & $<0.1$ & 1.1 \\
\hline 7 & 117 & -21.5 & $<0.02$ & 5.6 & 801 & 0.1 & 9.1 & $<0.1$ & 1.2 \\
\hline 15 & 133 & -21.6 & 1.5 & 24.3 & 925 & 1.2 & $<0.1$ & 12.3 & 5.6 \\
\hline P5 & 149 & -23.9 & 0.1 & 9.4 & 649 & $<0.1$ & 3.3 & 0.1 & 1.4 \\
\hline 8 & 155 & -21.4 & 2 & 2.2 & 803 & 0.1 & 195.7 & $<0.1$ & 4.4 \\
\hline U15 & 175 & n.a. & $<0.02$ & 0.1 & 939 & 0.1 & 12 & $<0.1$ & 1.8 \\
\hline U16 & 188 & n.a. & $<0.02$ & n.a. & 786 & $<0.1$ & 56.8 & n.a. & n.a. \\
\hline U17 & 213 & n.a. & $<0.02$ & 3 & 710 & $<0.1$ & 8.6 & $<0.1$ & 0.7 \\
\hline U19 & 218 & n.a. & $<0.02$ & n.a. & 721 & 0.2 & 45.5 & $<0.1$ & 1.2 \\
\hline
\end{tabular}






Fig. 3. Redox conditions at different locations shown for sampling campaign in 2006.

source of contamination. The data from these wells were divided into three categories (Fig. 3), "strongly reducing", "reducing" and "oxic" conditions. Wells were denoted as "strongly reducing" conditions when under sulphate-reducing and/or methanogenic conditions as indicated by $\mathrm{HS}^{-}>1 \mathrm{mg} \mathrm{L}^{-1}$ and/or $\mathrm{CH}_{4}>15 \mu \mathrm{g} \mathrm{L}^{-1}$. Wells with "reducing" conditions were characterised by denitrifying (depletion of nitrate below the reference value at E6p), iron- or manganese-reducing $\left(\mathrm{Fe}^{2+}\right.$ and/or $\left.\mathrm{Mn}^{2+}>1 \mathrm{mg} \mathrm{L}^{-1}\right)$ conditions. Finally, wells with "oxic" conditions were characterised by the absence of $\mathrm{CH}_{4}, \mathrm{HS}^{-}, \mathrm{Fe}^{2+}, \mathrm{Mn}^{2+}$, presence of $\mathrm{NO}_{3}^{-}$in concentrations comparable to the reference well E6p, and presence of $\mathrm{O}_{2}$ in groundwater (data not shown). "Strongly reducing" conditions were mainly encountered in the source zone and in its immediate vicinity to the East and South-East (Fig. 3). Concentrations of $\mathrm{HS}^{-}>1 \mathrm{mg} \mathrm{L}^{-1}$ in 8 out of 25 wells indicate that sulphate reduction is the predominant redox process at the site. Further to the East, conditions change to "moderately reducing" and finally "oxic" conditions.

In the 2006 sampling campaign, the highest benzene concentrations were found in D1p in the source area $\left(17,550 \mu \mathrm{g} \mathrm{L}^{-1}\right.$, Table 1$)$. In several other sampling points in the vicinity of the source area, benzene concentrations were $>1000 \mu \mathrm{g} \mathrm{L}^{-1}$, while concentrations rapidly decreased at locations further downgrading. At sampling wells located more than $80 \mathrm{~m}$ from D1p, benzene concentrations were $\leqslant 2 \mu \mathrm{g} \mathrm{L}^{-1}$. In these monitoring wells, no other BTEX, naphthalene (detection limit $5 \mu \mathrm{g} \mathrm{L}^{-1}$ ) or three-ring PAHs (detection limit $15 \mu \mathrm{g} \mathrm{L}^{-1}$ ) were detected.

\section{Fate of contaminants in the alluvial aquifer}

Specific investigations were performed, in both the laboratory and the field, in order to characterise the specific behaviour of existing contaminants in the brownfield site (sorption, degradation, etc.). These investigations were aimed at identifying the most problematic contaminants with respect to the off-site dispersion risk toward the Meuse River, and at proposing adequate scenarios to be modelled using the numerical groundwater flow and transport model presented in the section "Groundwater flow and transport modelling". These investigations focused therefore on the potential degradation of organic mono- and polycyclic aromatic hydrocarbons as well as on the characterisation of redox conditions as they possibly affect the mobility of inorganic pollutants.

\section{Fate of inorganic pollutants}

To determine the mobility of heavy metals present in the aquifer, groundwater and sediment were sampled between 8 and $12 \mathrm{~m}$ below ground level in well U15 (Fig. 1), located downgradient from the source area, where no organic pollutants have been detected till now.

Microcosms were set up in an anaerobic chamber at $20^{\circ} \mathrm{C}$ containing aquifer material $(10 \mathrm{~g})$ sampled and homogenised as described by Vanbroekhoven et al. (2007).

The soil-water distribution coefficients $\left(K_{d}\right)$ were calculated from the measured equilibrium concentrations in the batch tests:

$K_{d}=\left[\left(C_{i}-C_{f}\right) / C_{f}\right] L / S$

where $C_{i}$ and $C_{f}$ are the initial and final metal concentrations in solution within the batches $\left(\mathrm{mg} \mathrm{m}^{-3}\right)$, and $L / S$ is the liquid to solid ratio $\left(\mathrm{m}^{3} \mathrm{~kg}^{-1}\right)$.

The distribution coefficient $K_{d}$ expresses the ratio of the total amount of metals removed in the batches to the amount of metals in solution in equilibrium with the aquifer material. In the presence of a carbon source (i.e. acetate, which simulates organic contaminants as a carbon source), low available fractions were obtained for $\mathrm{Zn}(9 \%), \mathrm{Cd}$ (14\%), As (3\%) and for Co (13\%). Calculated $K_{d}$ values range from 9.9 to $27.8 \mathrm{~m}^{3} \mathrm{~kg}^{-1}$ for $\mathrm{Zn}$, from 0.75 to $9.9 \mathrm{~m}^{3} \mathrm{~kg}^{-1}$ for Cd, from 0.034 to $0.223 \mathrm{~m}^{3} \mathrm{~kg}^{-1}$ for As, and from 0.66 to $1.30 \mathrm{~m}^{3} \mathrm{~kg}^{-1}$ for Co. These high sorption constants suggest that heavy metals do not constitute a major risk in terms of off-site dispersion.

Assessment of benzene biodegradation using stable carbon isotope analysis

To determine residual concentrations of benzene in groundwater, samples were analysed with gas chromatography (Varian 3800) with a CP8410 autoinjector for solid phase microextraction 
(SPME). Benzene was extracted from the headspace of half-filled $2 \mathrm{~mL}$ sample vials using polydimethylsiloxane fibers $(100 \mu \mathrm{m}$ film thickness, Supelco, Bellefonte, PA). Degradation of benzene along the groundwater flow path was assessed and quantified using compound-specific carbon isotope analyses of groundwater samples. As demonstrated in laboratory studies, during aerobic (Hunkeler et al., 2001; Fischer et al., 2008) and anaerobic (Mancini et al., 2003; Fischer et al., 2008) degradation of benzene, a significant carbon isotope fractionation occurs because molecules consisting of light ${ }^{12} \mathrm{C}$ isotopes are degraded faster than those containing a heavy ${ }^{13} \mathrm{C}$ isotope. The remaining benzene resulting from isotope fractionation becomes increasingly enriched in ${ }^{13} \mathrm{C}$ which can be used to track the progress of biodegradation.

Groundwater from 16 wells containing residual benzene sampled in 2006 was analysed for stable carbon isotope ratios (Table 1). Benzene was extracted from groundwater using a Tekmar Velocity Purge \& Trap System and analysed using a Thermo Finnigan Trace gas chromatograph (GC) coupled to a Thermo Finnigan Delta Plus XP isotope ratio mass spectrometer (IRMS) via a GC combustion III interface.

The carbon isotope ratios are reported relative to the VPDB standard using the $\delta$-notation:

$\delta^{13} C[\% o]=\left(\frac{{ }^{13} C_{\text {sample }} /{ }^{12} C_{\text {sample }}}{{ }^{13} C_{\text {reference }} /{ }^{12} C_{\text {reference }}}-1\right) \times 1000$

where a $\delta^{13} \mathrm{C}$ shift in positive direction corresponds to an enrichment in ${ }^{13} \mathrm{C}$.

First-order biodegradation rates can be retrieved from isotope data using the following equation (Hunkeler et al., 2002; Blum et al., 2009):

$\lambda=-\Delta \delta^{13} C /(\varepsilon \times t)$

$\Delta \delta^{13} \mathrm{C}$ is the shift in the carbon isotope ratio between the source and a downgradient monitoring point, $\varepsilon$ is the isotope enrichment factor and $t$ the travel time. Travel times were estimated based on the average groundwater flow velocity $\left(1.04 \times 10^{-5} \mathrm{~m} \mathrm{~s}^{-1}\right)$, itself calculated from the average hydraulic gradient, saturated hydraulic conductivity and effective porosity.

\section{Natural attenuation of benzene}

Sampling locations in the source area with benzene concentrations $>10,000 \mu \mathrm{g} \mathrm{L}^{-1}$ were characterised by $\delta^{13} \mathrm{C}$ values of $-24.8 \%$ and $-23.5 \%$, while locations with lower concentrations were generally enriched in ${ }^{13} \mathrm{C}$. This clearly demonstrates the occurrence of biodegradation of benzene in the aquifer along the groundwater flow. The observed increase in $\delta^{13} \mathrm{C}$ was in the same range as previously observed at a gaswork site in Germany (Griebler et al., 2004). All of the sampling points with ${ }^{13} \mathrm{C}$ enriched benzene were located in zones with "strongly to moderately reducing" conditions (Fig. 3). Furthermore, benzene was degraded to concentrations below the limit of detection before the contaminant plume turned oxic again, underlining that benzene degradation at this site mainly occurred under anoxic conditions. Consequently, for the determination of the biodegradation rate constant using Eq. (3), an average carbon isotope enrichment factor of $\varepsilon=-2.4 \%$ for anaerobic benzene biodegradation was used. The isotope enrichment factor was determined in a laboratory study (Mancini et al., 2003). For benzene biodegradation, first-order rate constants were estimated for the section between the source zone and points located downgradient, taking into account only sampling points indicating "reducing" or "strongly reducing" conditions (D1p, U9, U4, U10, U13, 12, 7, or P5). Since the whole source zone (Fig. 4) was not only presenting irregular benzene concentrations but also different stable isotope signatures comprised between $-23 \%$ and $-24.8 \%$, we chose the piezometer D2bis $\left(\delta^{13} \mathrm{C}=-24.8 \%\right.$ o located at the Eastern (upgradient) fringe of the source zone and oriented towards the groundwater flow direction, as a reference point. A mean first-order degradation rate of $1.7 \times 10^{-2} / d$ was obtained. This rate constant for benzene is slightly higher, but in the same range as rate constants in a previous study on fuel contaminated sites and former gas plants in the USA $\left(3.3 \times 10^{-4} / d\right.$ to $4.4 \times 10^{-2} / d$; Lewandowski and Mortimer, $2004)$ and it is higher than values observed at six former manufactured gas plants in the US $\left(3.3 \times 10^{-4} / \mathrm{d}\right.$ to $4.1 \times 10^{-3} / \mathrm{d}$; Lewandowski and Mortimer, 2004).

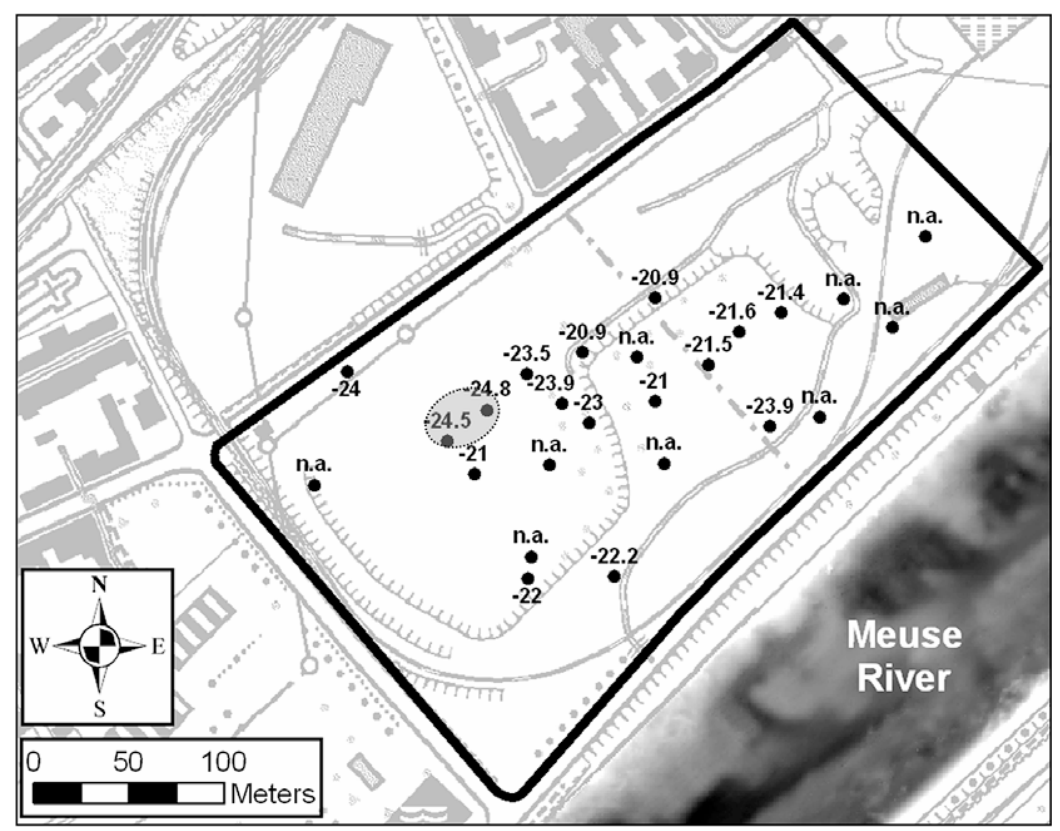

Fig. 4. $\delta^{13} \mathrm{C}$ isotope ratios of residual benzene in the groundwater of the field site. Highlighted in dark ellipse is the major source zone (n.a.: not analysed). 
Table 2

Heavy metals concentrations in groundwater sampled from three different piezometers in 2006 (concentrations are given in $\mu \mathrm{g} \mathrm{L}^{-1}$ ).

\begin{tabular}{lllllllllll}
\hline Well & $\mathrm{Zn}$ & $\mathrm{Cd}$ & $\mathrm{Co}$ & $\mathrm{Fe}$ & $\mathrm{Cu}$ & $\mathrm{Pb}$ & $\mathrm{Hg}$ & $\mathrm{Ni}$ & $\mathrm{As}$ & $\mathrm{Cr}$ \\
\hline $\mathrm{U} 15$ & 41.7 & 4.0 & 18.0 & $<1.95$ & 9.1 & 104.0 & $<0.1$ & 8.0 & 1.0 & 2.0 \\
$\mathrm{U} 17$ & $<1.52$ & $<1.84$ & 4.4 & 150.6 & $<2.65$ & $<26.52$ & $<0.1$ & 4.0 & 1.0 & 0.5 \\
$\mathrm{U} 23$ & $<1.52$ & 1.84 & 11.5 & 6496 & $<2.65$ & 19.0 & $<0.1$ & 1.0 & 5.0 & 0.2
\end{tabular}

\section{Summary on the fate of contaminants in the alluvial aquifer}

Based on previous investigations performed on contaminants that were detected in the brownfield site, the following conclusions can be drawn. Redox conditions at the site favour immobilisation of heavy metals, as demonstrated by Vanbroekhoven et al. (2007). These findings are confirmed by the low concentrations of metals detected in the groundwater in the field (Table 2). For the organic contaminants, the conclusions are not as straightforward, as PAHs seem to be relatively stable (i.e. naphthalene halflife: 139 days; acenaphthene half-life: 1386 days; Batlle-Aguilar et al., 2008). At the same time, they are known as being relatively immobile (strong sorption). BTEX and particularly benzene, are present at large concentrations and are potentially mobile. However, they have been shown to degrade in the alluvial aquifer. The presence of oxidants at the site, particularly sulphate, is one factor which could have contributed to the slightly higher biodegradation rate constant. Although site specific and always prone to uncertainties and variations, biodegradation rate constants for one particular contaminant can be assumed to be in the same order of magnitude under related environmental conditions. Therefore, cautiously applied, rate constants which were determined at one site might give important insights into further field scenarios. The calculated rate constant of benzene corresponds to a half-life of 41 days. When the half-life time is converted to the flow distance necessary for a mass reduction by a factor of two, $36 \mathrm{~m}$ are obtained. Given that the river is about $160 \mathrm{~m}$ from the source area in flow direction, a significant reduction of the benzene mass flux is expected before the river is reached.

The risk of BTEX dispersion depends of the balance between mobility and degradation effects along the flow path, downstream the pollutant sources. Furthermore, in downgradient parts of the plume, close to the river, biodegradation might be accelerated due to the fluctuation of the water table and also the infiltration of oxygen-rich river water (Williams and Oostrom, 2000).

Considering the above, benzene (as a representative of BTEX compounds) has been identified as the most critical pollutant present in the brownfield for short and middle terms risk of off-site dispersion towards the river. Subsequent modelling efforts have consequently been focused on this particular compound.

\section{Groundwater flow and transport modelling}

A numerical groundwater flow and transport model was developed in order to run different scenarios of benzene pollution using calculated degradation rates and to determine the risk of benzene off-site dispersion.

Development and calibration of the groundwater flow and transport model

The numerical groundwater flow model was developed using MODFLOW-2000 (Harbaugh et al., 2000). The limits of the modelled zone were extended to a larger part of the alluvial plain than that occupied by the brownfield, in order to fit the "natural" boundary conditions and to avoid the influence of self-defined boundary on modelling results (Fig. 5). Upstream, along the Meuse River (SW-boundary), the model was extended up to the Ivoz-Ramet dam, where a difference of $3 \mathrm{~m}$ in the Meuse River water level is produced by the dam, inducing a lateral "bypass" of surface water through the alluvial plain. At this boundary, piezometric levels are prescribed (Dirichlet boundary) at a level equal to the water level in the Meuse River upstream of the dam, inducing thus the mentioned surface water lateral "bypass". Downstream, along the



Fig. 5. Conceptual model of the groundwater flow and transport model. 
Meuse River (NE-boundary), the model is extended to 1-km downstream the brownfield. At this boundary, piezometric levels are prescribed (Dirichlet boundary) because there is no reason to think that no-flow may occur across that specific limit. Laterally (NWboundary), the modelled area is extended to the limit between the alluvial and the up-hill shaly bedrock. Because of the expected large difference in saturated hydraulic conductivity between the shaly bedrock and the alluvial deposits, a no-flow boundary condition was assumed. At the boundary between the Meuse River and the alluvial aquifer (SE-boundary), a third-type boundary condition (Fourier) is assumed to account for riverbank effect. The modelled domain is made of a single layer horizontally subdivided into 204 columns and 88 rows with variable grid refinement from $5 \mathrm{~m} \times 5 \mathrm{~m}$ inside the brownfield to $25 \mathrm{~m} \times 25 \mathrm{~m}$ at the edges of the regional modelled domain. More details on groundwater flow modelling can be found in Batlle-Aguilar and Brouyère (2008) and Batlle-Aguilar (2008).

The finite-difference groundwater flow model was calibrated and validated using the very detailed transient groundwater head dataset resulting from the monitoring performed with the pressiometric probes (see "Monitoring and analysis of interaction between rainfall, groundwater and surface water"). An innovative combined zonation-pilot point modelling approach automatically calibrated with Parameter Estimation Software - PEST (Doherty, 2003) was used. A classical zonation of saturated hydraulic conductivity values was used outside the brownfield, which was combined with the pilot points (de Marsily et al., 1984) distributed throughout the area corresponding to the brownfield. This combined approach, recently used by Doppler et al. (2007), allows an improved representation of the alluvial deposits heterogeneity within the brownfield. Daily groundwater heads monitored from 16 monitoring wells (Fig. 1) were used for the calibration of groundwater flow, applying a calibration target of $5 \mathrm{~cm}$. A comparison between the observed and modelled groundwater heads in several wells is presented in Fig. 6 to illustrate the quality of calibration. Modelled groundwater heads match well with measured ones (see Fig. 7) and show an efficient correlation coefficient $\left(R^{2}=0.967\right)$. Optimised values of saturated hydraulic conductivity ranged from $1 \times 10^{-5}$ to $1 \times 10^{-3} \mathrm{~m} \mathrm{~s}^{-1}$, lower than expected for an alluvial aquifer but not unrealistic for the alluvial Meuse River deposits (Brouyère, 2001).

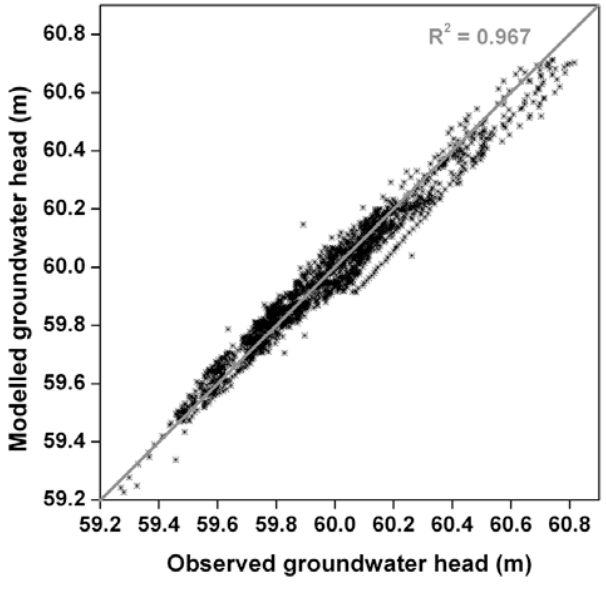

Fig. 7. Observed vs. modelled groundwater heads.

A transport model was developed using MT3DMS (Zheng and Wang, 1999). From the groundwater flow model developed using MODFLOW, a "submodel" of reduced dimensions corresponding almost to the studied brownfield was created for solute transport simulations (Fig. 5). This groundwater transport model has dimensions of $550 \mathrm{~m} \times 380 \mathrm{~m}$, with 159 columns and 113 rows and a variable grid refinement $0.5 \mathrm{~m} \times 0.5 \mathrm{~m}$ in the benzene source to $10 \mathrm{~m} \times 10 \mathrm{~m}$ at the limits of the model. Boundary conditions were considered as follows: a Fourier boundary condition in the contact area between the Meuse River and the aquifer (SE-boundary); prescribed time-varying piezometric head levels for the other boundaries (NE, NW and SW), which values come directly from the calibrated regional groundwater flow model. More details concerning the groundwater transport model are presented by Batlle-Aguilar and Brouyère (2008) and Batlle-Aguilar (2008).

The transport model was calibrated to fit measured breakthrough curves obtained in radially convergent tracer tests. To do so, the advection-dispersion equation (ADE) was considered, playing with longitudinal dispersion, dual-porosity effect and first-order transfer as fitting parameters to adjust observed to modelled tracer concentration and mass recovery at the pumping well (P5). Dual-porosity or mobile-immobile (MIM) water was consid-

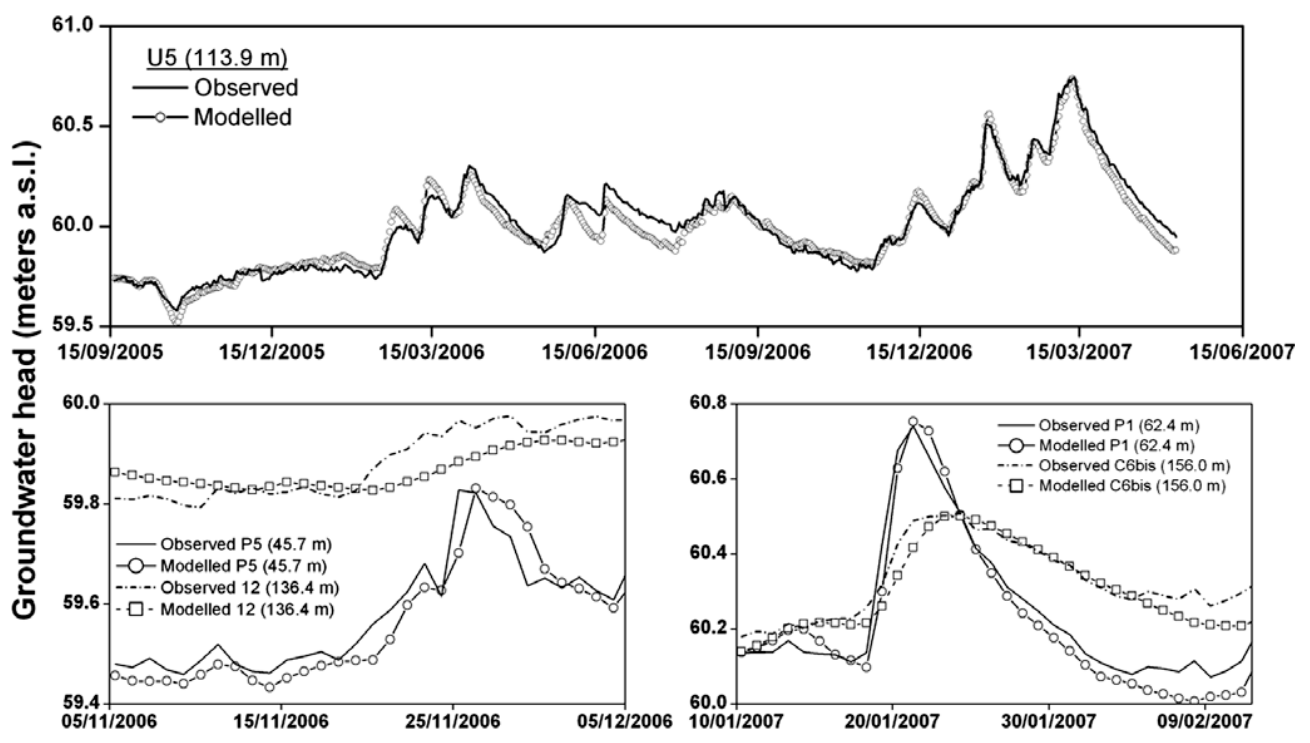

Fig. 6. Comparison between observed and measured groundwater heads at wells located near and far from the Meuse River for long and short modelled periods of time (distance between well and river is indicated in brackets). 
Table 3

Hydrodispersive parameters used for the calibration of tracer tests $\left(\theta_{m}\right.$ : mobile porosity; $\theta_{\text {im }}$ : immobile-or less mobile-porosity; $\alpha_{L}$ : longitudinal dispersivity; $\alpha$ : diffusion coefficient between mobile and immobile domains; $K_{d}$ : distribution coefficient between sorbed and dissolved phases; $p$ : fraction of sorption in contact with the immobile phase).

\begin{tabular}{lllllll}
\hline Tracer & $\theta_{m}(-)$ & $\theta_{i m}(-)$ & $\alpha_{L}(\mathrm{~m})$ & $\alpha\left(\mathrm{s}^{-1}\right)$ & $K_{d}\left(\mathrm{~m}^{3} \mathrm{~kg}^{-1}\right)$ & $p(-)$ \\
\hline Iodide & 0.041 & 0.10 & 1.4 & $4.50 \times 10^{-8}$ & - & - \\
Eosin yellowish & 0.060 & 0.05 & 3.0 & $1.60 \times 10^{-7}$ & - & - \\
Lithium & 0.068 & 0.70 & 4.5 & $1.05 \times 10^{-7}$ & $1.0 \times 10^{-4}$ & 0.91 \\
Uranine & 0.050 & 0.70 & 2.0 & $2.10 \times 10^{-7}$ & $1.0 \times 10^{-4}$ & 0.93 \\
Sulforhodamine B & 0.03 & 0.70 & 3.0 & $3.00 \times 10^{-7}$ & $7.6 \times 10^{-3}$ & 0.96 \\
Naphtionate & 0.047 & 0.10 & 2.2 & $2.10 \times 10^{-8}$ & - & - \\
\hline
\end{tabular}

ered in order to avoid difficulties in modelling tracer concentration attenuation and tailing for conservative tracers, such as iodide and eosin yellowish. The hydrodispersive parameters obtained in transport model calibration are summarised in Table 3. Mobile or effective porosity $\left(\theta_{m}\right)$ is indeed somehow low, with values ranging between 0.04 and 0.07 ; such effective porosity could be considered as low for alluvial gravels. However, related to the heterogeneity of the aquifer, this is relatively common for the alluvial deposits of the Meuse River (e.g. Brouyère, 2001; Rentier, 2002).

\section{Modelling benzene attenuation in the alluvial aquifer towards the} Meuse River

Although five characterisation campaigns were performed by SPAQuE at the studied site between 1992 and 2006, these data acquired do provide neither a spatial nor time continuity since the site is so heterogeneous. Among the 100 piezometers drilled within the brownfield during these campaigns, none of them has been sampled on a regular basis through time. In the best case, one or two measurements of contaminants are available in some of them and there is not enough information for any comparison between benzene concentrations observed in the field and calculated with the groundwater transport model. The approach is therefore to model different pollution scenarios in order to evaluate benzene dispersion and attenuation in the alluvial aquifer using the previously calibrated groundwater transport model together with biodegradation rates as estimated in the field as well as estimates of retardation constants coming from the literature.

The transport of benzene was modelled while considering firstly the steady state flow conditions, with the Meuse River level at its baseline (59.4 $\mathrm{m}$ a.s.l.) and the alluvial aquifer discharging into the river. The source of benzene of $2 \mathrm{~m} \times 2 \mathrm{~m}$, was placed at $165 \mathrm{~m}$ from the Meuse River and was modelled as a constant concentration equal to $750 \mathrm{mg} \mathrm{L}^{-1}$, which corresponds to the maximum benzene concentration measured in groundwater in the source area. Because piezometers in the brownfield are single screened, the vertical distribution of the benzene is not known and, thus, depth-average conditions were assumed. The different scenarios are compared on the basis of the maximum concentration evolutions calculated at five control planes (A, B, C, D and E) defined in the model between the source and the river, at respective distances of 25, 50, 80, 115 and $160 \mathrm{~m}$ from the source area (Fig. 8).

A total of five scenarios were modelled to study benzene transport in the aquifer (Table 4). Scenarios 1, 2 and 3 consider steady state groundwater flow conditions, starting from the worst contaminant scenario where only advection-dispersion and dualporosity processes are considered without sorption or degradation (scenario 1). Benzene retardation processes are then considered (scenario 2) assuming linear sorption. Then, benzene degradation is considered (scenario 3) assuming a first-order degradation model with degradation constants as estimated in the field using

\section{Table 4}

Benzene transport scenarios (ADE: advection-dispersion equation; MIM: mobileimmobile water; $\boldsymbol{\vee}$ : process considered in modelling tasks; $\times$ : process not considered in modelling tasks)

\begin{tabular}{|c|c|c|c|c|c|c|}
\hline Scenario & $\mathrm{ADE}$ & MIM & Sorption & Biodegradation & Steady state & Transient \\
\hline 1 & $r$ & $\nu$ & $\times$ & $x$ & $r$ & $x$ \\
\hline 2 & 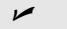 & $v$ & $v$ & $\times$ & $\boldsymbol{v}$ & $x$ \\
\hline 3 & $\nu$ & $\nu$ & $v$ & $v$ & $v$ & $x$ \\
\hline 4 & $v$ & レ & $r$ & $v$ & $\times$ & レ \\
\hline 5 & $v$ & $v$ & $x$ & $x$ & $\times$ & $v$ \\
\hline
\end{tabular}

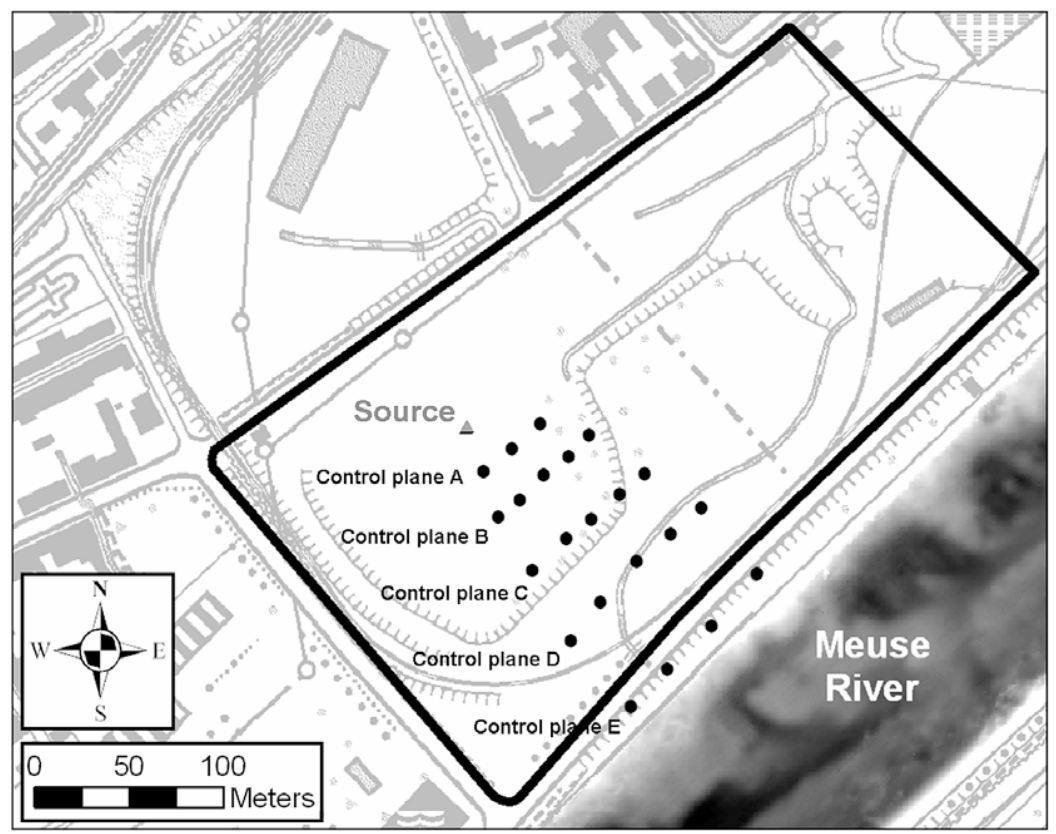

Fig. 8. Location of the main pollution source in the model and five control planes defined towards the river for modelling benzene transport in the aquifer 
the isotopic fractionation. In order to evaluate the influence of groundwater-surface water dynamics on benzene dispersion and attenuation in the alluvial aquifer, the model was run under transient conditions for 2 years (scenario 4), corresponding to the period when Meuse river levels and groundwater levels were monitored (from April 2005 to June 2007). Finally, an evaluation of the river fluctuations on benzene migration was performed in scenario 5 . This scenario is quite similar to scenario 4 but without considering benzene biodegradation and sorption. As initial conditions for scenarios $1-3$, benzene concentration was zero everywhere except in the source area. For scenario 4, initial conditions correspond to the stabilised benzene plume of scenario 3. Finally, the stabilised plume of scenario 1 was considered as initial condition in scenario 5 .

Mean values of hydrodispersive and retardation parameters obtained from the calibration of radially convergent tracer tests are used for the five scenarios (Table 5) and, where required, the linear distribution coefficient $\left(K_{d}\right)$ was calculated as follows:

$K_{d}=K_{o c} f_{o c}$

where $K_{o c}$ is the soil sorption coefficient for soil organic carbon $\left(\mathrm{L}^{3} \mathrm{M}^{-1}\right)$, and $f_{o c}$ is the fraction of soil organic carbon (-). For $K_{o c}$ and $f_{o c}$ characteristic values of alluvial aquifers were considered (Alvarez and Illman, 2006). The resulting $K_{d}$ value $\left(4.15 \times 10^{-5} \mathrm{~m}^{3} \mathrm{~kg}^{-1}\right)$ is in good agreement with values proposed by Fetter (1993) and used by van den Brink and Zaadnoordijk (1997) within a similar context.

The retardation factor $R$ was determined as follows:

$R=1+\left(\rho_{b} K_{d} / \theta_{m}\right)$

where $\rho_{b}$ is the bulk density $\left(\mathrm{M} \mathrm{L}^{-3}\right), K_{d}$ the distribution coefficient $\left(\mathrm{L}^{3} \mathrm{M}^{-1}\right)$ and $\theta_{m}$ the mobile porosity.

The first-order biodegradation rate constant for benzene biodegradation's estimation was based on the carbon isotope data using Eq. (3) (see details in "Assessment of benzene biodegradation using stable carbon isotope analysis" and "Natural attenuation of benzene" sections).

\section{Results on benzene transport modelling}

Benzene concentrations at control planes $A$ to $E$ for scenarios 1 (no retardation), scenario 2 (retardation by physic-chemical attenuation) and scenario 3 (including all NA processes) using a logarithmic scale are illustrated in Fig. 9. Although the retardation and attenuation of benzene were expected to be away from the source because of sorption and degradation, it is interesting to ob-

\section{Table 5}

Hydrodispersive and retardation parameters used for benzene transport simulations $\left(\theta_{m}\right.$ : mobile porosity; $\theta_{\text {im }}$ : immobile-or less mobile-porosity; $\alpha_{L}$ : longitudina dispersivity; $\alpha_{T}$ : transversal dispersivity; $\alpha$ : diffusion coefficient between mobile and immobile domains; $p$ : fraction of sorption in contact with the immobile phase; $R$ : retardation factor; $K_{d}$ : distribution coefficient between sorbed and dissolved phases; $K_{o c}$ : soil sorption coefficient for soil organic carbon; $f_{o c}$ : fraction of soil organic carbon; $\rho_{b}$ : bulk density; $\lambda$ : first-order degradation rate constant).

\begin{tabular}{ll}
\hline Hydrodispersive and retardation parameters & \\
\hline$\theta_{m}(-)$ & 0.04 \\
$\theta_{\text {im }}(-)$ & 0.1 \\
$\alpha_{L}(\mathrm{~m})$ & 2.5 \\
$\alpha_{T}(\mathrm{~m})$ & 0.5 \\
$\alpha\left(\mathrm{s}^{-1}\right)$ & $1 \times 10^{-7}$ \\
$p(-)$ & 0.95 \\
$R(-)$ & 3 \\
$K_{d}\left(\mathrm{~m}^{3} \mathrm{~kg}^{-1}\right)$ & $4.15 \times 10^{-5}$ \\
$K_{o c}\left(\mathrm{~m}^{3} \mathrm{~kg}^{-1}\right)$ & 0.083 \\
$f_{o c}(\%)$ & 0.05 \\
$\rho_{b}\left(\mathrm{~kg} \mathrm{~m}^{-3}\right)$ & 2000 \\
$\lambda\left(\mathrm{s}^{-1}\right)$ & $3 \times 10^{-7}$ \\
\hline
\end{tabular}

serve that degradation alone can explain the very low benzene concentrations near the river. For scenario 3 and with a degradation rate of $3 \times 10^{-7} \mathrm{~s}^{-1}$, benzene concentrations stabilise much faster in comparison to scenarios 1 and 2 , and concentrations are considerably reduced. Downgradient of control plane C $(80 \mathrm{~m})$, benzene concentrations are below $1 \times 10^{-6} \mathrm{mg} \mathrm{L}^{-1}$. Results of transient modelling of groundwater flow and transport are presented in Fig. 10. Benzene concentrations are presented at control plane B ( $50 \mathrm{~m}$ to the source area), together with the Meuse River levels and the groundwater levels for the same period. Benzene concentrations change over time inversely to river fluctuations. When the river water level fluctuates gently around its baseline (i.e. $59.4 \mathrm{~m}$ a.s.l.), the benzene concentration is at its maximum while when the river water level rises up to $61 \mathrm{~m}$ (hydraulic gradient inversion; e.g. January 2007), benzene concentration decreases to its minimum. This is due to the fact that the benzene plume moves backs as a consequence of the hydraulic gradient inversion between the river and the aquifer. When the river water level returns to its baseline, the benzene plume moves forward; this is translated in an increase of the benzene concentration. During the modelled period, benzene concentrations calculated in the zone adjacent to the river remain under the detection limit ( $\mu \mathrm{g} \mathrm{L}^{-1}$ ), which is in good agreement with sampling results obtained in 2005 and in 2006.

The impact of river fluctuations on benzene migration was studied by running the model for scenario 5 , where benzene degradation and sorption were not considered any longer. From Fig. 11 it is to observe that the benzene concentrations, being the same at the beginning of the simulation as those corresponding to scenario 1, are higher than concentrations presented in Fig. 10 for scenario 4. This further demonstrates that biodegradation is the main process controlling benzene migration in the aquifer. From a purely hydraulic point of view, the reversal of the groundwater flow direction is not efficient enough to prevent benzene migration off-site to the Meuse River.

\section{Discussion}

It was observed in the field that benzene was present at concentrations on the order of $\mathrm{mg} \mathrm{L}^{-1}$ in the source zone and also that these concentrations decreased of several orders of magnitude within a relatively short distance downstream from the source. As an example, benzene concentrations on the order of $\mu \mathrm{g} \mathrm{L} \mathrm{L}^{-1}$ have been reported in piezometer $\mathrm{U} 10$, located $115 \mathrm{~m}$ downgradient the source and located at a distance of about $50 \mathrm{~m}$ from the Meuse River (corresponding to control plane D). The numerical model demonstrated that a plume formed more than 25 years ago (i.e. at least around 1984, at which time industrial activities in the brownfield were stopped definitively and installations were demolished) would extend much further the downgradient source, in the absence of biodegradation and under the assumption of a constant benzene source of $750 \mathrm{mg} \mathrm{L}^{-1}$. Consequently, high concentrations of benzene should be observed in groundwater close to the river. However, benzene was never detected in the different sampling points located in shorter distance to the Meuse River (U15, U17, P4). The strong decrease in the benzene concentrations over such a short distance can be attributed to biodegradation under strongly reducing conditions, as confirmed by the enrichment of ${ }^{13} \mathrm{C}$ in benzene with increasing distance from the source. When biodegradation is considered in the model, concentrations below $10 \mu \mathrm{g} \mathrm{L}^{-1}$ are predicted at locations downgradient control plane $\mathrm{B}$, which matches well with the measured data (Table 1). This conclusion is in agreement with a recent field study that used a stable isotope-based first-order decay model to investigate the natural attenuation of BTEX and naphthalene (Blum et al., 2009). 

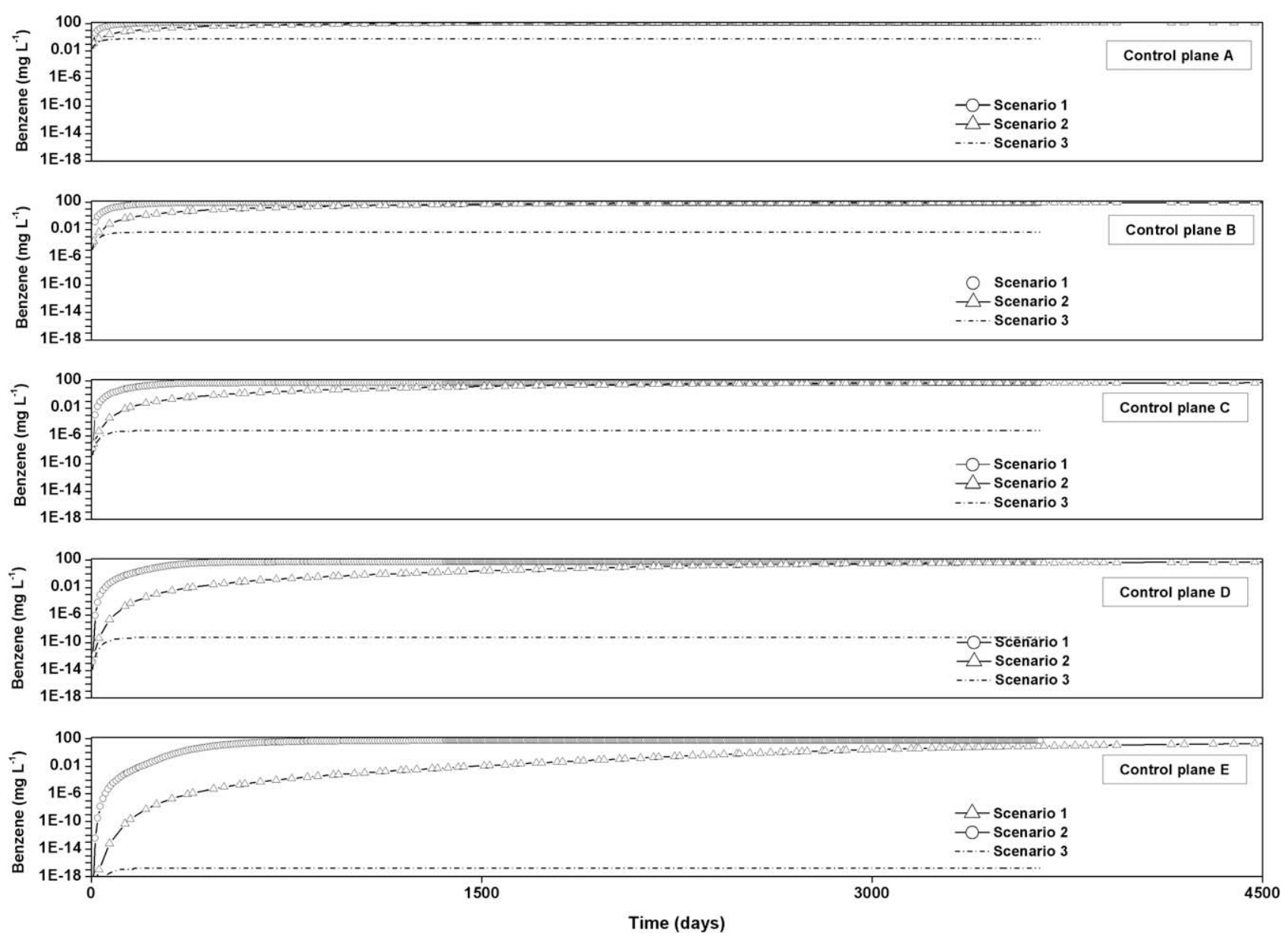

Fig. 9. Steady state benzene concentrations (logarithmic scale) at control planes A, B, C, D and E for scenarios 1 (no sorption), $2(R=3)$ and $3\left(\lambda=3 \times 10^{-7} \mathrm{~s}^{-1}\right.$ ) (see Table 4 for details).

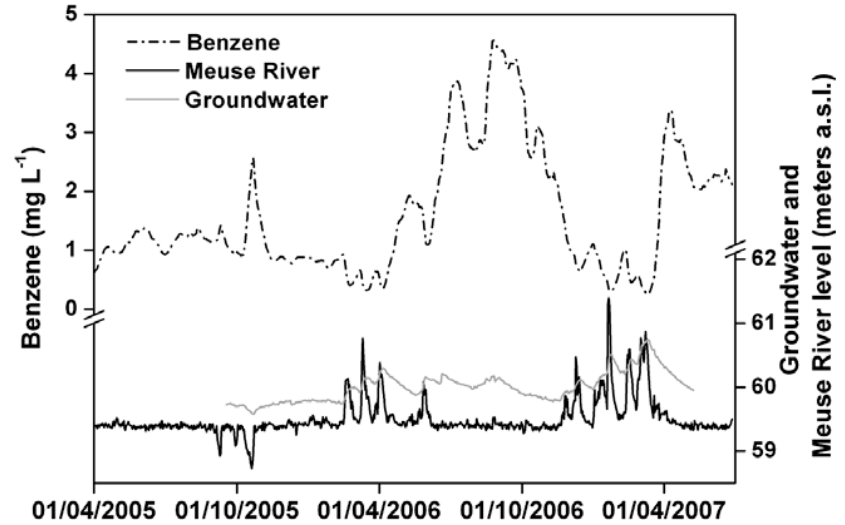

Fig. 10. Modelled transient benzene concentrations at control plane $B(50 \mathrm{~m}$ to the source area) for a period of 2 years (scenario 4 ; see Table 4 for details).

Considering the redox map of the site (Fig. 3), it becomes evident that benzene is mainly biodegraded under sulphate-reducing conditions. In particular, $\mathrm{HS}^{-}$concentrations higher than $1 \mathrm{mg} \mathrm{L}^{-1}$ are observed in zones where benzene concentrations are larger than $1 \mathrm{mg} \mathrm{L}^{-1}$ in groundwater, therefore confirming this assumption. The potential for anaerobic biodegradation of benzene in the aquifer material from the site was also confirmed by a laboratory microcosm study, under in situ like conditions, using ${ }^{13} \mathrm{C}$ labeled substances. In these microcosms, $140 \mathrm{mg} \mathrm{L}^{-1}$ of sulphate

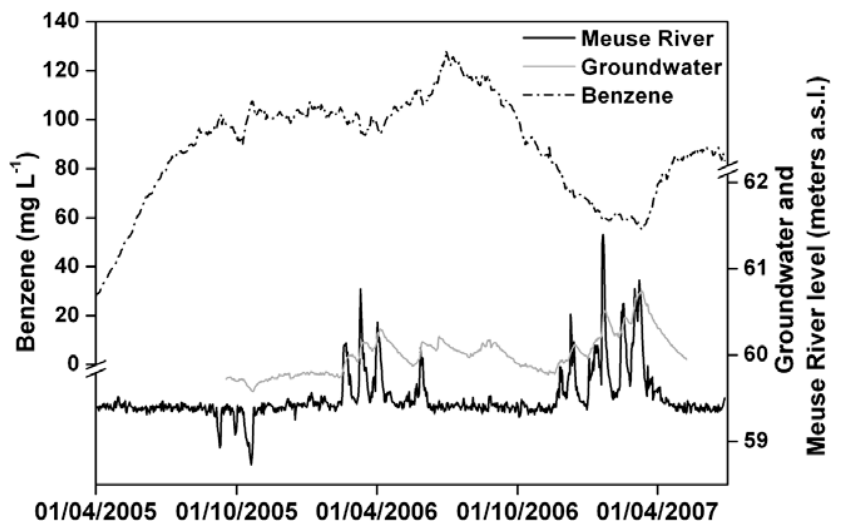

Fig. 11. Modelled transient benzene concentrations at control plane $B(50 \mathrm{~m}$. to the source area) for a period of 2 years (scenario 5 ; see Table 4 for details).

as main electron acceptor were initially added to groundwater from the field site and mineralisation of benzene was observed (Morasch et al., 2007). A complementary batch study with aquifer material and groundwater from the site was performed to investigate the fate of heavy metals (Vanbroekhoven et al., 2007). The decrease in sulphate was monitored during degradation of acetate as an easily available carbon source and the effect of sulphide on heavy metal concentrations in the water phase was followed over time. 
Based on these two microcosm approaches, it can be assumed that the immobilisation of divalent metals like $\mathrm{Zn}$ and $\mathrm{Cd}$ as metalsulphides is likely to take place in the aquifer and might be linked to the degradation of organic contaminants. The hypothesis could also explain the low concentrations of divalent $\mathrm{Zn}$ and $\mathrm{Cd}$ in the groundwater sampled from piezometers U15 (Vanbroekhoven et al., 2007). On the contrary, reducing conditions are expected to lead to a mobilisation of As(III).

Biodegradation processes have proved to be the main factor preventing benzene migration off-site. However, near the river, the fate of benzene or other organic contaminants could still be influenced by groundwater-surface water interaction as follows. Firstly, contaminants might be diluted by infiltrating river water which would decrease measured concentrations without removing the benzene out of the system. Secondly, infiltrating river water might stimulate biodegradation by supplying oxidants or nutrients. For PAHs such as naphthalene and acenaphthene, which can be biodegraded in the aquifer under anoxic conditions but at relatively low rates (Morasch et al., 2007), biodegradation by infiltrating river water might be even more pronounced. Finally, in areas where organic pollutants have not been reported (e.g. around piezometers U15 and U17), oxic conditions still prevail. In this case, $\mathrm{As}(\mathrm{III})$ might be converted to $\mathrm{As}(\mathrm{V})$ and immobilised; on the contrary, $\mathrm{Zn}$ and $\mathrm{Cd}$ would be released.

\section{Conclusions and perspectives}

Under prevailing conditions, the risk of contaminant dispersion to the Meuse River through groundwater discharge seems low. The largest fraction of benzene, and possibly also of other monoaromatic contaminants, is predominantly degraded under sulphatereducing conditions. The sulphide that is released by contaminant degrading bacteria can lead to the precipitation of divalent cations $\mathrm{Zn}$ and $\mathrm{Cd}$ as their metalsulphides. Further downgradient source and closer to the river, a natural attenuation of more persistent organic contaminants could probably be enhanced by groundwater-surface water interactions. That is, groundwater level being influenced by river water level fluctuations, because surface water infiltration can induce the possible dilution of the front of the plume and supply oxidants, enhancing thus benzene biodegradation. As long as sulphate remains available at elevated levels, one can expect an efficient attenuation of organic compounds and a subsequent immobilisation of heavy metals such as $\mathrm{Zn}$ and $\mathrm{Cd}$ in the strongly reduced zone of the aquifer. It would be helpful firstly, to gain more insight into the long term availability of sulphate and secondly, to evaluate the temporal evolution of contaminant concentrations under the influence of fluctuating river levels in further details. Finally, there is a need for batch experiments directly linking the degradation of organic contaminants with the precipitation and dissolution of metal cations, under various reduced conditions. The use of a more advanced reactive transport modelling that incorporates geochemical processes would also provide additional understanding and knowledge on contaminant dispersion in the studied site, in particular or their possible interactions.

\section{Acknowledgements}

This work was supported by the European Union FP6 Integrated Project AquaTerra (Project No. 505428) under the thematic priority, sustainable development, global change and ecosystems, by the Belgian BELSPO through the SSD FRAC-WECO project no. SD/ $\mathrm{TE} / 02 \mathrm{~A}$ and by ULg Aquapôle research funds. Thanks to SPAQuE, especially $\mathrm{H}$. Halen and A. Lox, for access to data and to the brownfield. Thanks are also due to P. Theunissen (SPE-TGV) for his gracious contribution on Meuse data time series. Florian Châtelain is thanked for his assistance during benzene degradation field campaigns and for helping with the groundwater analysis. Authors gratefully thank Marie Sudki for editing and polishing of the English writing.

\section{References}

Alvarez, P.J.J., Illman, W.A., 2006. Bioremediation and natural attenuation: process fundamentals and mathematical models. Environmental Science and Technology. John Wiley \& Sons, Hoboken, New Jersey, USA, 609 pp.

Batlle-Aguilar, J., 2008. Groundwater flow and contaminant transport in an alluvial aquifer: in situ investigation and modelling of a brownfield with strong groundwater-surface water interactions. Ph.D Thesis. Faculté de Sciences Appliqués, ArGEnCo department, University of Liège, Belgium, 245 pp.

Batlle-Aguilar, J., Brouyère, S., 2005. Documentation of site equipment and description of experiments performed and still planned in the former cokery test site A. Deliverable R3.15. Report Basin R3.15. AquaTerra (Integrated Project FP6 no. 505428), 22 pp.

Batlle-Aguilar, J., Brouyère, S., 2006. Update on field experiments and description of the groundwater flow and transport model for the cokery site A. Report Basin R3.19. AquaTerra (Integrated Project FP6 no. 505428), 50 pp.

Batlle-Aguilar, J., Brouyère, S., 2008. Groundwater flow and transport model for the Flémalle cokery site. Report Basin R3.25. AquaTerra (Integrated Project FP6 no. 505428), 34 pp.

Batlle-Aguilar, J., Brouyère, S., Dassargues, A., Diels, L., Vanbroekhoven, K., Hunkeler D., Morasch, B., Halen, H., 2008. Hydrodynamic characterisation of a groundwater-surface water system and evaluation of BTEX, PAHs decay and heavy metal fate. In: Proceedings of the Conference ConSoil'08, Milano, Italy, Theme G, pp. 71-80.

Blum, P., Hunkeler, D., Weede, M., Beyer, C., Grathwohl, P., Morasch, B., 2009 Quantification of biodegradation for o-xylene and naphthalene using first order decay models, Michaelis-Menten kinetics and stable carbon isotopes. Journal of Contaminant Hydrology, doi:10.1016/j.jconhyd.2008.11.009.

Brouyère, S., 2001. Etude et modélisation du transport et du piégeage des solutés en milieu souterrain variablement saturé (study and modelling of transport and retardation of solutes in variably saturated media). Ph.D. Thesis, Faculté des Sciences Appliquées. Laboratoire de géologie de l'ingénieur, d'Hydrogéologie et de Prospection géophysique, Université de Liège, Liège, Belgium, 640 pp.

Burland, S.M., Edwards, E.A., 1999. Anaerobic benzene biodegradation linked to nitrate reduction. Appl. Environ. Microbiol. 65 (2), 529-533.

Cline, J.D., 1969. Spectrophotometric determination of hydrogen sulfide in natural waters. Limnol. Oceanogr. 14, 454-458.

Conant, B.J., Cherry, J.A., Gillham, R.W., 2004. A PCE groundwater plume discharging to a river: influence of the streambed and near-river zone on contaminant distributions. J. Contam. Hydrol. 73, 249-279.

de Marsily, G., Lavedan, G., Boucher, M., Fasanino, G., 1984. Interpretation of interference tests in a well field using geostatistical techniques to fit the permeability distribution in a reservoir model. In: Verly et al. (Eds.) Proceedings of Geostatistics for natural resources characterization. Part 2. D. Reidel Pub. Co., pp. 831-849.

Doherty, J., 2003. Ground water model calibration using pilot points and regularization. Ground Water 41 (2), 170-177.

Doppler, T., Franssen, H.-J.H., Kaiser, H.-P., Kuhlman, U., Stauffer, F., 2007. Field evidence of a dynamic leakage coefficient for modelling river-aquifer interactions. J. Hydrol. 347, 177-187.

Fetter, C.W., 1993. Contaminant Hydrogeology. MacMillan, New York. 458 pp.

Fischer, A., Herklotz, I, Herrmann, S, Thullner, M. Weelink, S.A B Stams, A.J.M. Schlomann, M., Richnow, H.H., Vogt, C., 2008. Combined carbon and hydrogen isotope fractionation investigations and elucidating benzene biodegradation pathways. Environ. Sci. Technol. 42 (12), 4356-4363.

Fischer, A., Theuerkorn, K., Stelzer, N., Gehre, M., Thullner, M., Richnow, H.H., 2007. Applicability of stable isotope fractionation analysis for the characterization of benzene biodegradation in a BTEX-contaminated aquifer. Environ. Sci. Technol. $41,3689-3696$.

Fleckenstein, J.H., Niswonger, R.G., Fogg, G.E., 2006. River-aquifer interactions, geologic heterogeneity, and low flow management. Ground Water 44 (6), 837852.

Fritz, B.G., Arntzen, E.V., 2007. Effect of rapidly changing river stage of uranium flux through the hyporheic zone. Ground Water 45 (6), 753-760.

Goto, K., Taguchi, S., Fukue, Y., Ohta, K., Watanabe, H., 1977. Spectrophotometric determination of manganese with 1-(2-pyridylazo)-2-naphtol and a non-ionic surfactant. Talanta 24 (12), 752-753.

Griebler, C., Safinowski, M., Vieth, M., Richmond, H.H., Meckenstock, R.U., 2004. Combined application of stable isotope analysis and specific metabolites determination for assessing in situ degradation of aromatic hydrocarbons in a tar oil-contaminated aquifer. Envrion. Sci. Technol. 38 (2), 617-631.

Ha, K., Koh, D.-C., Yum, B.-W., Lee, K.-K., 2007. Estimation of layered diffusivity and river resistance using flood wave response model. J. Hydrol. 337, 284-293.

Harbaugh, A.W., Banta, E.R., Hill, M.C., McDonald, M.G., 2000. MODFLOW-2000: the US geological survey modular ground-water model. User guide to modularization concepts and the ground-water flow process. Open-File Report 00-92. US Geological Survey, Reston, Virginia, 121 pp.

Herr, M., Schäfer, G., Spitz, K., 1989. Experimental studies of mass transport in porous media with local heterogeneities. J. Contam. Hydrol. 4, 127-137. 
Hunkeler, D., Andersen, N., Aravena, R., Bernasconi, S.M., Butler, B.J., 2001. Hydrogen and carbon isotope fractionation during aerobic biodegradation of benzene. Environ. Sci. Technol. 35 (17), 3462-3467.

Hunkeler, D., Höhener, P., Zeyer, J., 2002. Engineered and subsequent intrinsic in situ bioremediation of a diesel fuel contaminated aquifer. J. Contam. Hydrol. 59, 231-245.

Jha, M.K., Jayalekshmi, K., Machiwal, D., Kamii, Y., Chikamori, K., 2004. Determination of hydraulic parameters of an unconfined alluvial aquifer by the floodwave-response technique. Hydrogeol. J. 12, 628-642.

Kao, C.M., Wang, C.C., 2000. Control of BTEX migration by intrinsic bioremediation at a gasoline spill site. Water Res. 34 (13), 3413-3423.

Khan, R., Israili, S.H., Ahmad, H., Mohan, A., 2005. Heavy metals pollution assessment in surface water bodies and its suitability for irrigation around the Neyveli lignite mines and associated industrial complex, Tamil Nadu, India. Mine Water Environ. 24 (3), 155-161.

Lee, J.-Y., Cheon, J.-Y., Lee, K.-K., Lee, S.-Y., Lee, M.-H., 2001. Factors affecting the distribution of hydrocarbon contaminants and hydrogeochemical parameters in a shallow sand aquifer. J. Contam. Hydrol. 50, 139-158.

Lee, S.-W., Lee, B.-t., Kim, J.-y., Kim, K.-w., Lee, J.-s., 2006. Human risk assessment for heavy metals and as contamination in the abandoned metal mine areas, Korea. Environ. Monit. Assess. 119, 233-244.

Lewandowski, G., Mortimer, G., 2004. Estimation of anaerobic biodegradation rate constants at MGP sites. Ground Water 42 (3), 433-437.

Li, L., Barry, D.A., Culligan-Hensley, P.J., Bajracharya, K., 1994. Mass transfer in soils with local stratification of hydraulic conductivity. Water Resour. Res. 30 (11), 2891-2900.

Lovley, D.R., 2000. Anaerobic benzene degradation. Biodegradation 11 (2-3), 107116

Mancini, S.A., Ulrich, A.C., Lacrampe-Couloume, G., Sleep, B., Edwards, E.A., Lollar, B.S., 2003. Carbon and hydrogen isotopic fractionation during anaerobic biodegradation of benzene. Appl. Environ. Microbiol. 69, 191-198.

Morasch, B., Höhener, P., Hunkeler, D., 2007. Evidence for in situ degradation of mono-and polyaromatic hydrocarbons in alluvial sediments based on microcosm experiments with 13C-labeled contaminants. Environ. Pollut. 148 (3), 739-748.
Pinault, J.-L., 2001. Manuel utilisateur de TEMPO. Logiciel de traitement et de modélisation des séries temporelles en hydrogéologie et en hydrogéochimie. RP-51459-FR. BRGM, Orléans, France, 233 pp.

Platen, H., Schink, B., 1987. Methanogenic degradation of acetone by an enrichment culture. Arch. Microbiol. 149 (2), 136-141.

Rentier, C., 2002. Méthode stochastique de délimitation des zones de protection autour des captages d'eau. Ph.D Thesis. Faculté des Science Appliquées. Department GEOMAC, Université de Liège, Liège, Belgium, 212 pp.

Sophocleous, M.A., 1991. Stream-floodwave propagation through the Great Bend alluvial aquifer, Kansas: field measurements and numerical simulations. J. Hydrol. 124, 207-228.

Stucki, J.W., Anderson, W.L., 1981. The quantitative assay of minerals for $\mathrm{Fe}^{2+}$ and $\mathrm{Fe}^{3+}$ using 1, 10-Phenanthroline. 1. Sources of variability. Soil Sci. Soc. Am. J. 45 (3), 633-637.

van den Brink, C., Zaadnoordijk, W.J., 1997. Nonequilibrium transport and sorption of organic chemicals during aquifer remediation. Hydrol. Sci. 42, 245264 .

Vanbroekhoven, K., Van Roy, S., Gielen, C., Maesen, M., Ryngaert, A., Diels, L., Seuntjens, P., 2007. Microbial processes as key drivers for metal (im) mobilization along a redox gradient in the saturated zone. Environ. Pollut. $148,759-769$.

Wiedemeier, T.H., Rifai, H.S., Newell, C.J., Wilson, J.T., 1999. Natural Attenuation of Fuels and Chlorinated Solvents in the Subsurface. Wiley, NewYork. 617 pp.

Williams, M.D., Oostrom, M., 2000. Oxygenation of anoxic water in a fluctuating water table system: an experimental and numerical study. J. Hydrol. 230, 7085.

Wroblicky, G.J., Campana, M.E., Valett, H.M., Dahm, C.N., 1998. Seasonal variation in surface-subsurface water exchange and lateral hyporheic area of two streamaquifer systems. Water Resour. Res. 34 (3), 317-328.

Zheng, C., Wang, P.P., 1999. MT3DMS: a modular three-dimensional multispecies transport model for simulation of advection, dispersion, and chemical reactions of contaminants in groundwater systems; documentation and user's guide. Contract Report SERDP-99-1. US Army Engineer Research and Development Center, Vicksburg, MA, USA, 202 pp. 